\title{
Potential Effects of Food Processing Byproducts on Neurological and Immunological Disorders of Obese Rats
}

\author{
Eman B. Mehram ${ }^{1}$, Alaa O. Aboraya ${ }^{2}$ and Yousif A. Elhassaneen ${ }^{3 *}$
}

\begin{abstract}
The present study aims to explore the effect of three byproducts that result from food processing processes, namely onion and bananas peels, and apricot seeds on neurological and immunological disorders of obese rats. Feeding of rats on diet induced obesity (DIO) leads to increase the BW than the control group. At the end of the experiment ( 8 weeks), rats of the normal group recorded $131.33 \%$ of baseline for the BW while obese group was $197.25 \%$ of baseline. Replacement of diets starch with banana peel powder (BPP), onion skin powder (OSP), apricot seeds powder (ASP) and their mixture induced significant decreasing on $\mathrm{BW}$ of the obese rats which recorded $177.85,155.41,173.59$ and $144.83 \%$ of baseline, respectively. The higher effect on weigh decreasing was recorded for the plant parts mixtures followed by OSP, ASP and BPP, respectively. On the other side data has demonstrated the potency of the selected food processing byproducts including BPP, ROSP, ASP and their mixture to ameliorate the neurological (dopamine and serotonin content and acetylcholine esterase activity) and immunological (serum albumin and tumor necrosis factor$\alpha$ content, and protease activity) disorders in obese rats. These findings provide a basis for the use of the selected food processing byproducts for the prevention and early treatment of obesity. Also, the data support the benefits of dietary modification, including food processing byproducts supplementation, in alleviating neurological and immunological disorders associated obesity.
\end{abstract}

Keywords: Body weight banana peel, onion skin, apricot seeds, acetylcholine esterase, dopamine, serotonin, albumin, tumor necrosis factor and protease activity.

\section{INTRODUCTION}

Obesity is a complex disease that results from the inappropriate control of the body's energy balance leads to excess adipose tissue mass. Over half of adults are overweight and $19.5 \%$ of the adult populations are obese in Organization for Economic Co-operation and Development member countries (OECD, 2017). According to the World Health Organization (WHO), there are more than one billion overweight adults in the world. At least 300 million of them are clinically obese
(WHO, 2006) and of these about 115 million come from developing countries (WHO and Dini, 2006). Egypt, a developing country, is undergoing rapid urbanization changes. This has a direct impact on its people's dietary habits and physical activity patterns. According to national studies, it is common to skip meals and to replace them with daily snacks, and most of these snacks are high in calories and low in nutrients. So, Egypt appeared in No. 8 ranking among the countries of the world where obesity - adult prevalence rate, 30.3\% (http:// www.indexmundi.com/ egypt/ obesity adult_ prevalence rate. html).

It is well known that obesity is a risk factor for several malignancies including hepatic, pancreatic, thyroid, uterine and colon cancer and for diabetes mellitus and cardiovascular diseases (Gukovsky et al., 2013; Alzahrani et al., 2014 and Mokdad, 2003). Also, obesity is consequent to a loss of the balance between energy intake and expenditure over long periods of time, and the brain plays a principal role in controlling and inhibiting the pre-potent responses to foods (Morton et al., 2014). On the other side, epidemiologic studies suggest that obesity is known as risk factor for neurodegenerative diseases (Loef and Walach, 2013) such as Alzheimer's disease (AD). AD is a the most prevalent form of dementia which characterized by a cumulative decline in memory, cognitive functions and behavior in the elderly population (Albert et al., 2011). Several studies reported that correlation studies have shown that obesity was associated with decreased brain volume, altered brain structure and function deficits in learning, memory and executive function, alterations and reduction in focal gray matter volume (Pannacciulli et al., 2006 and Pistell et al., 2010).

Epidemiological studies have reported that consumption of plant parts imparts health benefits, e.g. reduced risk of diabetics, obesity, coronary heart disease, stroke, and certain types of cancer (Elhassaneen et al., 2016 a-d; and Elmaadawy et al., 2016). Apart from dietary fiber, these health benefits are mainly attributed to many organic micronutrients including

DOI: 10.21608/asejaiqjsae.2021.178864

${ }^{1}$ Home Economics Department, Faculty of Specific Education,

Benha University, Benha.

${ }^{2}$ Department of Nutrition and Food Science, Faculty of Home Economics,

Helwan University, Cairo.

3*Department of Nutrition and Food Science, Faculty of Home Economics,

Minoufiya University, Shebin El-Kom, Egypt.

*Corresponding authors: yousif12@ hotmail.com

Received May 15, 2021, Accepted, June 21, 2021. 
phytochemicals, vitamins and others. Food processing in the arab countries represent a large proportion of waste/byproducts was estimated at 18.14 million tons per year and represent remnants of vegetables and fruit processing about $6.14 \%$ of this amount (http://elasaala.blogspot.com/2012/01/blog-post_2703. html). Waste in the food processing is characterized by a high ratio of product-specific waste/by-products. Food processing by-products/plant parts could be considered a good source of phytochemicals. They are a large group of plant-derived compounds such as phenolic compounds (phenolic acids and flavonoids), terpenes, volatile oils and nitrogen compounds (indoles), and organosulphur containing compounds hypothesized to be responsible for much of the disease protection including obesity provided by diets high in by-products of fruits, vegetables, herbs, beans, cereals, plant-based beverages etc (Elhassaneen et al., 2016 a-d). We will limit our study here to three of the by-products that result from food processing activities which are onion and banana peels, and apricot seed/kernels_apricot (Primus armeniaca L.; Rosacea family) is mostly grown in Mediterranean countries, Pakistan, Russia, USA and Iran. Apricot seeds are waste of the apricot processing industry. It is used partially used as apricot seed oil in cosmetics and peeled seeds as a raw material for the processing of persipan (reviewed in Schieber et al., 2001). Apricot seed/kernel oil is a rich source of monounsaturated fatty acids (MUFA) and polyunsaturated fatty acids (PUFA), including mainly oleic $(\sim 70 \%)$ and linoleic acids, respectively. Additionally, apricot kernel oil could be considered as a good source of different bioactive compounds such as phytosterols and tocopherols (Hassan, 2011 and Tahoon, 2019). Onion (Allium cepa L.) belongs to family, Alliaceae and represent one of the most important crop around the world including Egypt. The amount of onion waste produced annually in the European Union is estimated at approximately 450,000 tons. Onion skins are a source of flavour components and fiber compounds and particularly rich in quercetin glycosides, phenolics, carotenoids (Hertog, et al., 1992; Waldron, 200, Elhassaneen and Sanad, 2009, and Hassan, 2015). Banana (Musa sapientum) belongs to the family Musaceae which has already provided human with food, tools and shelter prior to recorded history (Ngwang, 2015). Its play an important role in the economy and food security of many wet tropical regions in the world (Coulibaly et al., 2007). Peels represent about $30-40 \mathrm{~g} / 100 \mathrm{~g}$ of fruit weight. Significant quantities of banana peels equivalent to $40 \%$ of the total weight fresh banana are generated as a waste product in industries producing banana based products (Ragab et $a l ., 2016)$. Banana fruit peel has a broad spectrum of biological activities and include be used as a good source of antioxidant and antitumor agent (Kumar et al., 2012). In addition to banana peels extracts are promising sources of natural antioxidants total phenol (Kumar, 2015) and Bioactive compounds such as alkaloids, anthocyanin, flavonoids, glycosides, phlobatannins, tannins and terpenoids.

Many studies have discovered the protective effect of such plant parts on different complications including serum lipid profile, hyperglycemia, cardiovascular disease, atherosclerosis, liver and kidney functions (Elhassaneen et al., 2016 a-d; and Elmaadawy et al., 2016) in obese experimental animal model. But till now, there are no studies were conducted to explore the effect of these foods processing byproducts consumption on neurological and immunological complications in obese rat. To fill the information gap, the present study was designed to investigate whether consumption of apricot kernels, onion skin, banana peels and their mixture would alleviate neurological and immunological disorders in obesity rat model.

\section{MATERIAL AND METHODS}

\section{MATERIALS}

By-products: Yellow onion skin (Allium cepa L.) was obtained from the New Beni Suef company for Preservation, Dehydration and Industrialization of Vegetables, Beni Suef Elgudida City, Beni Suef, Egypt; and banana (Musa sapientum) and apricot (Primus armeniaca L.) fruits were obtained from Benha City market, Benha Governorate, Egypt, transported to the laboratory and used immediately for peels and seeds powder preparation.

Chemicals, solvents and buffers: All chemicals, solvents and buffers (except mentioned on site) were purchased from Al-Gomhoryia Company for Trading Drugs, Chemicals and Medical Equipment's, Cairo, Egypt. Serotonin, dihydroxybenzylamine (DHBA) as internal standard, perchloric acid $\left(\mathrm{HCIO}_{4}\right), \mathrm{Na}_{2} \mathrm{HPO}_{4}$, citric acid, $\mathrm{Na}_{2}$ EDTA, and heptanesulfonic acid (HSA) were purchased from Egyptian agent of Sigma Chemical Co. (St. Louis, MO). The water employed in all solutions was purified through a Nanopure II system (Thermo Fisher Scientific, Waltham, MA)

\section{METHODS}

\section{Preparation of by-products peel powder Banana peels powder (BPP)}

Banana fruits were washed, peeled and sliced to get the peels then dried in a hot air oven (Horizontal Forced Air Drier, Proctor and Schwartz Inc., Philadelphia, PA) at $55^{\circ} \mathrm{C}$ for 14 hours. The dried peels were ground into a fine powder in high mixer speed (Moulinex Egypt, AlAraby Co., Egypt). The material that passed through an 80 mesh sieve was retained for use. 


\section{Onion peel powder (OPP)}

Yellow onion skin peel were washed and then dried in a hot air oven (Horizontal Forced Air Drier, Proctor and Schwartz Inc., Philadelphia, PA) at $60{ }^{\circ} \mathrm{C}$ for 12 hours. The dried skins were milled to a fine powder in high mixer speed (Moulinex Egypt, Al-Araby Co., Egypt). The material that passed through an 80 mesh sieve was retained for use.

\section{Apricot seed powder (ASP)}

Unripe apricot fruits were washed, sliced to get the kernels and crushed to extract the seeds. The seeds were treated to remove all toxic substances according to the methods mentioned by Galanakis, (2019) and dried at $60{ }^{\circ} \mathrm{C}$ for 8 hours in hot air oven (AFOS Mini Smoker, England). Dried parts followed by milling with miller (Retsch Micro Universal Bench Top Grinder, Germany) to produce the proper powder type. The material that passed through an 80 mesh sieve was retained for use.

\section{Biological Experiments}

\section{Animals}

Animals used in this study, adult male albino rats $(145 \pm 10 \mathrm{~g}$ per each) were obtained from Research Institute of Ophthalmology, Medical Analysis Department, Giza, Egypt.

\section{Basal Diet}

The basic/standard diet prepared according to the following recipes as mentioned by AIN, (1993) as follow: casein/protein (10\%), corn oil (10\%), vitamin mixture $(1 \%)$, mineral mixture $(4 \%)$, choline chloride $(0.2 \%)$, methionine $(0.3 \%)$, cellulose $(5 \%)$, and the remained is corn starch $(69.5 \%)$. The Diet Induced Obesity (DIO) was prepared according to Research Diets, Inc. NJ, USA, as follow: casein, 80 mesh (23.3\%), L-cystine (0.35\%), corn starch (8.48\%), maltodextrin $(11.65 \%)$, sucrose $(20.14 \%)$, soybean oil (2.91\%), animal/lamb fat (20.69\%), mineral mixture $(1.17 \%)$, dicalcium phosphate $(1,52 \%)$, calcium carbonate $(0.64 \%)$, potassium citrate $1 \mathrm{H}_{2} \mathrm{O}(1.92 \%)$, vitamin mixture $(1.17 \%)$, choline bitartrate $(0.23 \%)$. The used vitamins and salt mixtures components were constituted according to Campbell, (1963) and Hegested, (1941), respectively.

\section{Experimental design}

All biological experiments performed a complied with the rulings of the Institute of Laboratory Animal Resources, Commission on life Sciences, National Research Council (NRC, 1996). Rats ( $\mathrm{n}=36$ rats), $145 \pm 10 \mathrm{~g}$ per each, were housed individually in wire cages in a room maintained at $24 \pm 2{ }^{\circ} \mathrm{C}$ and kept under normal healthy conditions. All rats were fed on basal diet for one-week before starting the experiment for acclimatization. After one week period, the rats were divided into two main groups, the first group (Group 1,
6 rats) still fed on basal diet and the other main group (30 rats) was feed with diet-induced obesity (DIO) (Research Diets, Inc. NJ, USA) for 8 weeks which classified into sex sub groups as follow: group (2), fed on DIO as a positive control; group (3), fed on DIO containing $5 \%$ BPP; group (4), fed on DIO containing 5 $\%$; OSP, group (5), fed on DIO containing $5 \%$ ASP and group (6): fed on DIO containing $5 \%$ mixture, BPP, OSP and ASP by equal parts. Body weight gain (as percent of initial weight) was assayed every week in rats.

\section{Blood sampling}

At the end of experiment period, eight weeks, blood samples were collected from rats after twelve hours fasting using the abdominal aorta and rats were scarified under ethyl ether anesthetized. Blood samples were received into clean dry centrifuge tubes and left to clot at room temperature then centrifuged for ten minutes at $3000 \mathrm{rpm}$ to separate the serum according to Drury and Wallington, (1980). Serum was carefully aspirate, transferred to clean tubes and stored at $-20{ }^{\circ} \mathrm{C}$ until use.

\section{Hematological analysis}

\section{Level of Dopamine and serotonin}

Levels of dopamine and serotonin in serum were measured by Elisa methods and LDN kits (Germany).

\section{Acetylcholinestrase (AChE) determination}

Serum AChE activity (Rappaport units $/ \mathrm{mL}$ ) was assayed according to the colorimetric method mentioned by Gowenlock, (1988).

\section{Albumin}

Albumin was determined in plasma using kits purchased from El-Nasr Pharmaceutical Chemicals Company, Cairo, Egypt.

\section{Protease activity assay}

The protease activity was determined according to the method of Rinderrnecitt et al., (1968). In brief, 100 $\mu \mathrm{l}$ of plasma were added to $40 \mu \mathrm{l}$ of buffer $(150 \mathrm{mM}$ Tris base, $30 \mathrm{mM} \mathrm{CaCl}_{2}, 0.05 \%$ Brij 35) and $50 \mu \mathrm{l}$ of protease substrate (20\% Hide powder azure, HPA, $20 \%$ sucrose, $0.05 \%$ Brij). The tubes contents were incubated at $37^{\circ} \mathrm{C}$ with continuous shaking for 2 hours. The reaction was stopped by the addition of $50 \mu \mathrm{l}$ of $10 \%$ TCA and the tubes were stored at $4 \mathrm{C}$ for about $15 \mathrm{~min}$. After spined the tubes at $8500 \mathrm{rpm}$ for $5 \mathrm{~min}$, the supernatants were transferred to new tubes and the absorbencies were measured at $540 \mathrm{~nm}$. Blank tubes were prepared by the same previous steps without samples addition.

\section{TNF- $\alpha$ assay}

TNF- $\alpha$ was determined by a sandwich enzymelinked immeunosorbent assay (ELISA), utilizing two monoclonal antibodies directed against separate 
antigenic determinants on rat TNF- $\boldsymbol{\alpha}$. The kits for the assay were provided by Adlitteram Diagnostic Laboratories Inc. (San Diego, CA, USA).

\section{Statistical Analysis}

All samples analysis were carried in tree times and recorded as mean \pm standard deviation (SD). Statistical analysis was done by using Student $t$-test and MINITAB-12 computer program (Minitab Inc., State College, PA).

\section{RESULTS AND DISCUSSION}

\section{The effect of selected food processing byproducts on body weight of obese rats}

The effect of selected food processing byproducts on body weight of obese rats was shown in Table (1) and Figure (1). From such data it could be noticed that feeding of rats on diet induced obesity (DIO) leads to increase the BW than the control group. At the end of the experiment (8 weeks), rats of the normal group recorded $131.33 \%$ of baseline for the body weight while obese group was $197.25 \%$ of baseline. Alteration of diets starch with banana peel powder (BPP), onion skin powder (OSP), apricot seeds powder (ASP) and their mixture exhibited significant $(\mathrm{p} \leq 0.05)$ decreasing on body weight of the obese rats which recorded 177.85, $155.41,173.59$ and $144.83 \%$ of baseline, respectively. The higher effect on weigh decreasing was recorded for the plant parts mixtures followed by OSP, ASP and BPP, respectively. The effect of different food processing byproducts including OSP, ASP and BPP in the control of obesity is the main topics of several studies (El-Safty, 2012; Bonet et al., 2015; Elmaadawy et al., 2016; Sayed Ahmed, 2016; Aly et al., 2017; Mahran et al., 2018-a and Saad et al., 2018).
The positive effects of such selected foods processing byproducts regarding the control of the obesity could be attributed to their high level content of different categories of phytochemicals including alkaloids, phenolic acids, anthocyanins, carotenoids, flavonols, organosulfur compounds and phytosterols (Onyeneho and Hettiarachchy, 1993; Rodriguez et al., 1994; Velioglu et al., 1998; Beattic et al., 2005; Bedawy, 2008; Hassan, 2011; Mahran et al., 2018-b and Saad et al., 2018). Also,

Erdogan-orhan and Kartal, (2010) reported that apricot seeds oil (ASO) is a rich source of monounsaturated fatty acids and polyunsaturated fatty acids, including mainly oleic (about $70 \%$ ) and linoleic acids, respectively. In addition, ASO could be considered as a good source of bioactive compounds such as tocopherols and phytosterols consisting mainly of the $\alpha$-isomer and $\beta$-sitosterol, respectively. Due to its high content of essential fatty acids, ASO is considered as a healthy supplement in diet.

Such phytochemicals groups have been shown to impact gene expression and cell (including adipocyte) function through one or several of the following mechanisms, interacting with several transcription factors of the nuclear receptor superfamily, interfering with the activity of other transcription factors, modulating signaling pathways which are associated with inflammatory and oxidative stress responses, and extra-genomic actions such scavenging of reactive species (Constance et al., 2003; Bray, 2004; Bonet et al., 2015, Elmaadawy et al., 2016; Sayed Ahmed, 2016 and Mahran et al., 2018-a) . Subsequently, all of these mechanisms participate to their action control of adipocyte function, adiposity and obesity.

Table 1. The effect of selected food processing byproducts on body weight gain (g) of obese rats*

\begin{tabular}{lccccccccc}
\hline \multirow{2}{*}{ Groups } & \multicolumn{10}{c}{ Feeding period (weeks) } \\
\cline { 2 - 10 } & $\mathbf{0}$ & $\mathbf{1}$ & $\mathbf{2}$ & $\mathbf{3}$ & $\mathbf{4}$ & $\mathbf{5}$ & $\mathbf{6}$ & $\mathbf{7}$ & $\mathbf{8}$ \\
\hline Control (-) Std diet & 151.02 & 158.57 & 187.72 & 220.36 & 247.06 & 285.11 & 314.97 & 335.79 & $349.35^{\mathrm{e}}$ \\
Control (+) Obese & 151.02 & 183.63 & 205.53 & 249.45 & 296.82 & 380.49 & 421.40 & 430.83 & $448.91^{\mathrm{a}}$ \\
Banana peel powder (BPP) & 151.02 & 164.99 & 187.60 & 229.94 & 273.60 & 334.26 & 356.69 & 382.60 & $413.18^{\mathrm{b}}$ \\
Onion skin powder (OSP) & 151.02 & 154.26 & 175.40 & 214.98 & 255.81 & 312.52 & 333.49 & 366.03 & $385.72^{\mathrm{c}}$ \\
Apricot seeds powder & 151.02 & 169.22 & 190.46 & 233.44 & 277.77 & 339.35 & 388.81 & 406.35 & $419.61^{\mathrm{b}}$ \\
(ASP) & & & & & & & & & \\
Mixture (BPP+ OSP+ASP) & 151.02 & 167.18 & 199.69 & 229.61 & 265.63 & 314.11 & 335.19 & 350.10 & $369.75^{\mathrm{d}}$ \\
\hline
\end{tabular}

Means in the same column with different superscript letters are significantly different at $\mathrm{p} \leq 0.05$. 


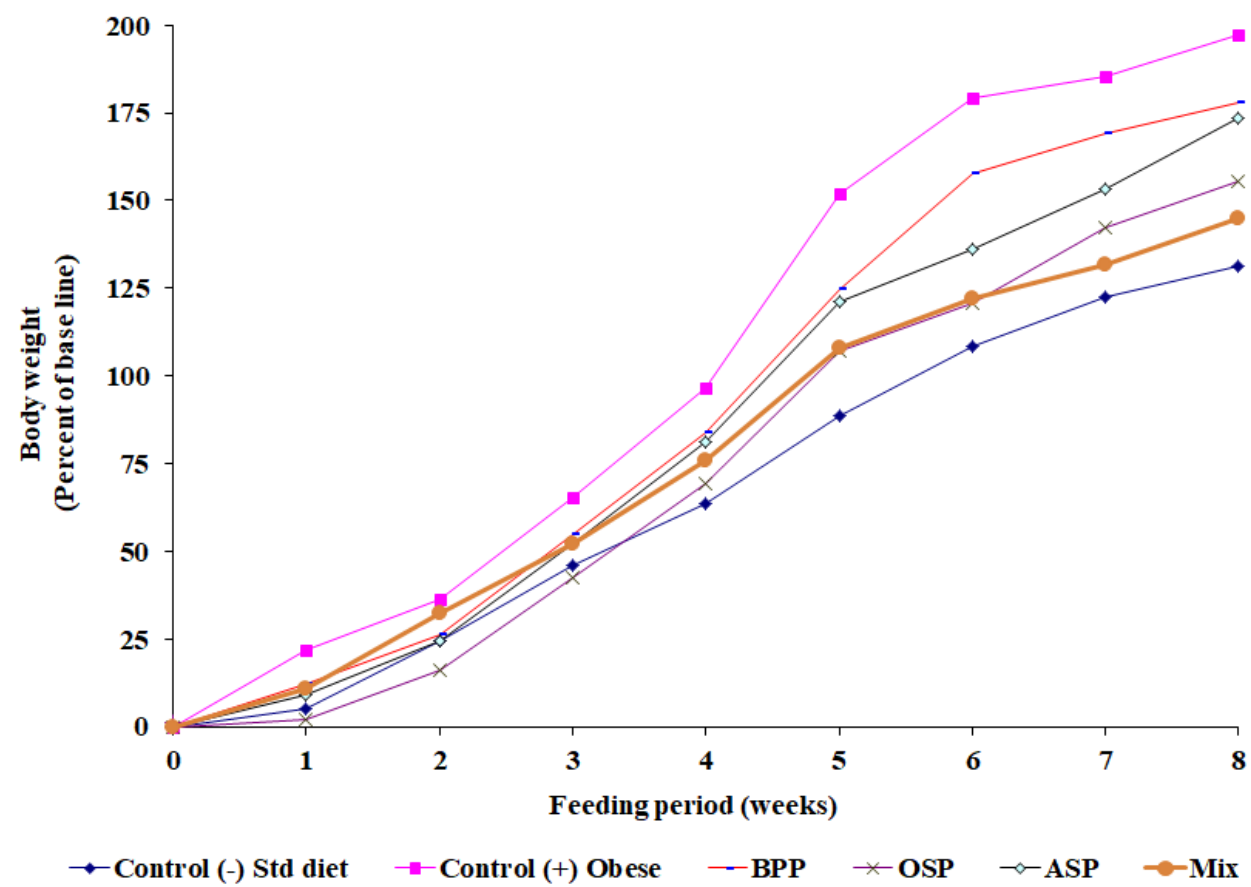

Fig. 1. The effect of selected food processing byproducts on body weight gain (Percent of baseline) of obese rats*

*BPP, banana peel powder; OSP, onion skin powder; ASP, apricot seeds powder and Mix, mixture of BPP, OSP and ASP by equal parts.

The effect of selected food processing byproducts on neurological complications of obese rats

\section{a) Serum neurotransmitters (dopamine and serotonin)}

The effect of selected food processing byproducts in neurotransmitters, dopamine and serotonin of obese rats were shown in Table (2) and Figure (2). Such data indicated that obesity induced a significant $(\mathrm{p} \leq 0.05)$ decreasing in dopamine (-14.93\%) and serotonin ($13.91 \%$ ) levels compared to the normal group. Alteration of BPP, OSP, ASP and their mixture exhibited significant $(\mathrm{p} \leq 0.05)$ increasing on serum dopamine and serotonin levels by the ratio of -10.34 , $6.95,-7.96$ and $-5.07 \%$; and $-11.48,-8.62,-10.97$ and $5.93 \%$, respectively. The highest improvement in neurotransmitters disorders induced by obesity in rats were recorded for the byproducts mixture treatment followed by OSP, ASP, and BPP, respectively.

Dopamine and serotonin (catecholamines) are neurotransmitters that are produced in different zones of the body including of the abdomen, back and brain. Dysfunction of the dopamine and serotonin system has been implicated in different nervous system diseases such as a complicated with obesity (Nam et al., 2018).
Several studies reported that dopamine and serotonin as neurotransmitters involved in the regulation of food intake and body weight (Lam et al., (2010). Also, Nam et al., (2018) investigated relationship between obesity and the availabilities of striatal dopamine and extrastriatal serotonin transporters. They also found that obesity has an effect on midbrain serotonin transporter availability and body mass index was correlated with pontine serotonin transporter availability but not with striatal dopamine transporter availability. On the other side, Morton et al., (2014) reported that brain plays a critical role in controlling and inhibiting the prepotent responses to foods.

Our data revealed that variety of bioactive compounds such as found in the present selected food processing byproducts i.e. BPP, OSP, ASP and their mixture that demonstrate neurological disorders potential amelioration effects. That decreasing in neurotoxic effects was depending on the type of the food processing byproducts applied. Neurological disorders treatment is described as the ability of bioactive compounds such antioxidants, to promote healthy neurological functions. Certain bioactive compounds have been shown in experimental studies to have neurostimulating properties; that is, they appear to 
help stimulate neurotransmitance mechanisms by activating catecholamine's transmitters such dopamine and serotonin (Mousseau, and Baker, 2012; and Hugo et al., 2016). To interpret such mechanism, L'opez-P'erez et al., (2015) mentioned that dopamine is breakdown enzymatically to its inactive metabolites by different enzymes mainly monoamine oxidase (MAO). The inhibition of MAO which could be induced by obesity and/or obesity complications has been considered as an adjunctive therapy in neurodegenerative disorders. Such phenomena was observed by in Alzheimer's and Parkinson's diseases (Mousseau and Baker, 2012).
Beside MAO inhibitors, hydrogen peroxide $\left(\mathrm{H}_{2} \mathrm{O}_{2}\right)$ production as the results of oxidative stress (OS) induced by obesity and/or its complications could be a co-factor could be helped in neurodegenerative disorders (Hugo et al., 2016). Neurons have different antioxidant systems, for example, catalase (CAT) and glutathione (GSH), to cope with $\mathrm{H}_{2} \mathrm{O}_{2}$ production. In similar studies, Mahran et al., (2018) and Elbasouny et al., (2019) reported that different plant parts including the selected food processing byproducts inducing the different antioxidant systems in live cells such serum

Table 2. The effect of selected food processing byproducts on serum dopamine and serotonin of obese rats*

\begin{tabular}{|c|c|c|c|c|c|c|}
\hline \multirow[b]{2}{*}{ Value } & \multirow[b]{2}{*}{$\begin{array}{c}\text { Control } \\
\qquad(-) \\
\text { Std diet }\end{array}$} & \multirow[b]{2}{*}{$\begin{array}{c}\text { Control } \\
(+) \\
\text { Obese }\end{array}$} & \multicolumn{4}{|c|}{ Food processing byproducts Conc. $(5 \%, w / w)$} \\
\hline & & & $\begin{array}{c}\text { Banana peel } \\
\text { powder } \\
\text { (BPP) }\end{array}$ & $\begin{array}{c}\text { Onion skin } \\
\text { powder } \\
\text { (OSP) }\end{array}$ & $\begin{array}{c}\text { Apricot seeds } \\
\text { powder } \\
\text { (ASP) }\end{array}$ & $\begin{array}{c}\text { Mixture } \\
\text { (BPP + OSP } \\
\text { + ASP) } \\
\end{array}$ \\
\hline \multicolumn{7}{|c|}{ Serum dopamine level $(\mathrm{pg} / \mathrm{ml})$} \\
\hline Mean & $89.2^{\mathrm{a}}$ & $75.89^{\mathrm{c}}$ & $79.99^{\mathrm{bc}}$ & $83.01^{\mathrm{b}}$ & $82.11^{\mathrm{b}}$ & $84.69^{b}$ \\
\hline SD & 5.65 & 6.11 & 4.78 & 8.10 & 5.21 & 7.55 \\
\hline$\%$ of Change & 0.00 & -14.93 & -10.34 & -6.95 & -7.96 & -5.07 \\
\hline \multicolumn{7}{|c|}{ Serum serotonin level $(\mathrm{ng} / \mathrm{ml})$} \\
\hline Mean & $220.32^{\mathrm{a}}$ & $189.67^{\mathrm{d}}$ & $195.03^{\mathrm{c}}$ & $201.32^{\mathrm{bc}}$ & $196.15^{\mathrm{c}}$ & $207.25^{b}$ \\
\hline SD & 18.98 & 19.36 & 9.23 & 14.23 & 15.25 & 11.45 \\
\hline$\%$ of Change & 0.00 & -13.91 & -11.48 & -8.62 & -10.97 & -5.93 \\
\hline
\end{tabular}

* Means in the same row with different superscript letters are significantly different at $p \leq 0.05$.

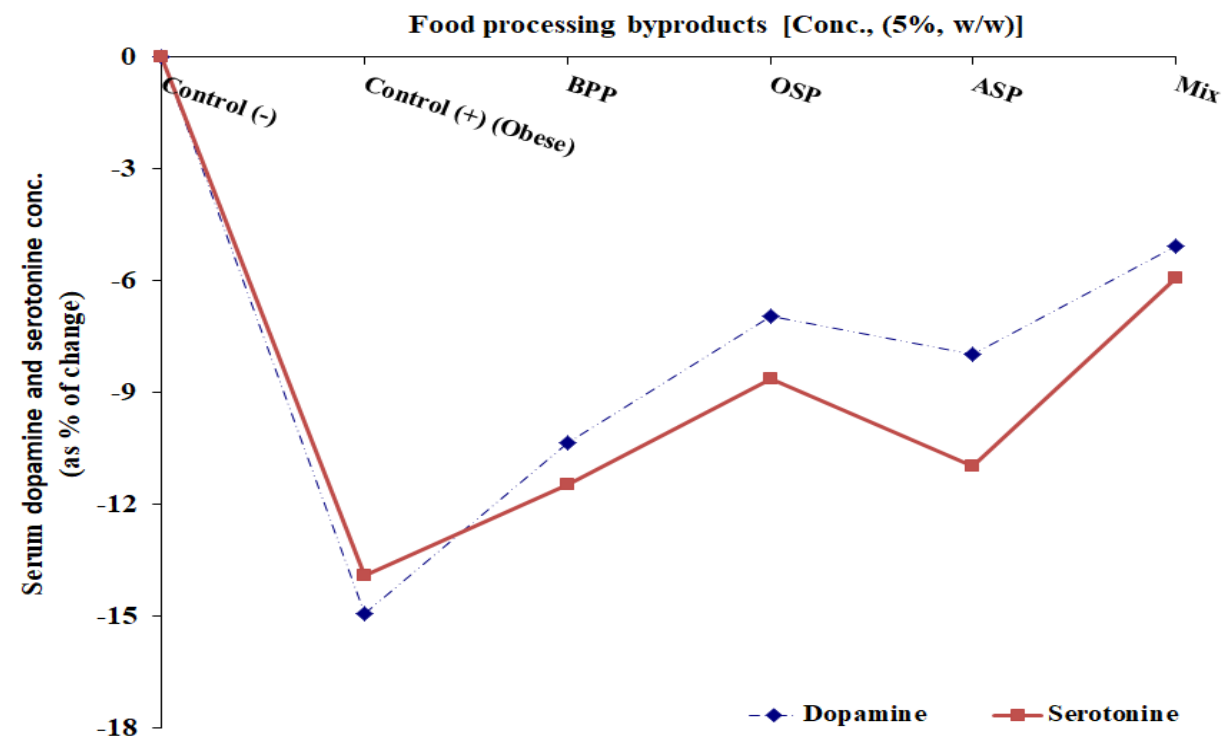

Fig. 2. The effect of selected food processing byproducts on serum dopamine and serotonin concentration (as $\%$ of change) of obese rats*

*BPP, banana peel powder; OSP, onion skin powder; ASP, apricot seeds powder and Mix, Mixture of BPP, OSP and ASP by equal parts 
glutathione (GSH) and antioxidant enzymes including CAT which cope $\mathrm{H}_{2} \mathrm{O}_{2}$ and neutralization/ prevents MAO inhibitors. Also, the study of Thomsen, (2013) reviewed that $\mathrm{OS}$ and $\mathrm{H}_{2} \mathrm{O}_{2}$ have been implicated as the underlying factors in the initiation and progression of Parkinson's disease. Increases in endogenous $\mathrm{H}_{2} \mathrm{O}_{2}$ in the dorsal striatum attenuated electrically evoked dopamine release and also decreased basal dopamine levels. The present data with the others suggested that the highest therapeutic effect was recorded for the mixture of the selected food processing byproducts could be attributed to the antagonism effects of their content of different categories bioactive compounds. Such observation was confirmed by the studies of Elmaadawy et al., (2016); Sayed Ahmed, (2016) and Mahran et al., (2018-a).

\section{b. Serum acetylcholine esterase (AChE) activity}

The effect of selected food processing byproducts in serum AChE activity of obese rats was shown in Table (3) and Figure (3). Such data indicated that obesity induced a significant $(\mathrm{p} \leq 0.05)$ increasing in serum AChE 16.80\%) level compared to the normal group. Alteration of BPP, OSP, ASP and their mixture exhibited significant $(\mathrm{p} \leq 0.05)$ decreasing on serum AChE levels by the ratio of 11.06, 8.04, 11.22 and $4.91 \%$, respectively. The highest improvement in serum AChE activity induced by obesity in rats was recorded for the byproducts mixture treatment followed by OSP, $\mathrm{BPP}$, and ASP, respectively.

Table3.The effect of selected food processing byproducts on serum acetylcholine esterase (ACE, Rappapor $\mathrm{U} / \mathrm{mL}$ ) of obese rats*

\begin{tabular}{lcccccc}
\hline \multirow{2}{*}{ Value } & $\begin{array}{c}\text { Control } \\
(-)\end{array}$ & $\begin{array}{c}\text { Control } \\
(+)\end{array}$ & \multicolumn{4}{c}{ Food processing byproducts (5\%, w/w) } \\
\cline { 4 - 7 } & $\begin{array}{c}\text { Std diet } \\
\text { Obese }\end{array}$ & $\begin{array}{c}\text { Banana peel } \\
\text { powder } \\
(\text { BPP) }\end{array}$ & $\begin{array}{c}\text { Onion skin } \\
\text { powder } \\
(\text { OSP) }\end{array}$ & $\begin{array}{c}\text { Apricot seeds } \\
\text { powder (ASP) }\end{array}$ & $\begin{array}{c}\text { Mixture (BPP } \\
+ \text { OSP + ASP) }\end{array}$ \\
\hline Mean & $67.45^{\mathrm{c}}$ & $78.78^{\mathrm{a}}$ & $74.91^{\mathrm{a}}$ & $72.87^{\mathrm{ab}}$ & $75.02^{\mathrm{a}}$ & $70.76^{\mathrm{ab}}$ \\
SD & 4.11 & 9.65 & 5.86 & 7.43 & 5.67 & 7.11 \\
$\%$ of Change & 0.00 & 16.80 & 11.06 & 8.04 & 11.22 & 4.91 \\
\hline
\end{tabular}

* Means in the same row with different superscript letters are significantly different at $\mathrm{p} \leq 0.05$.

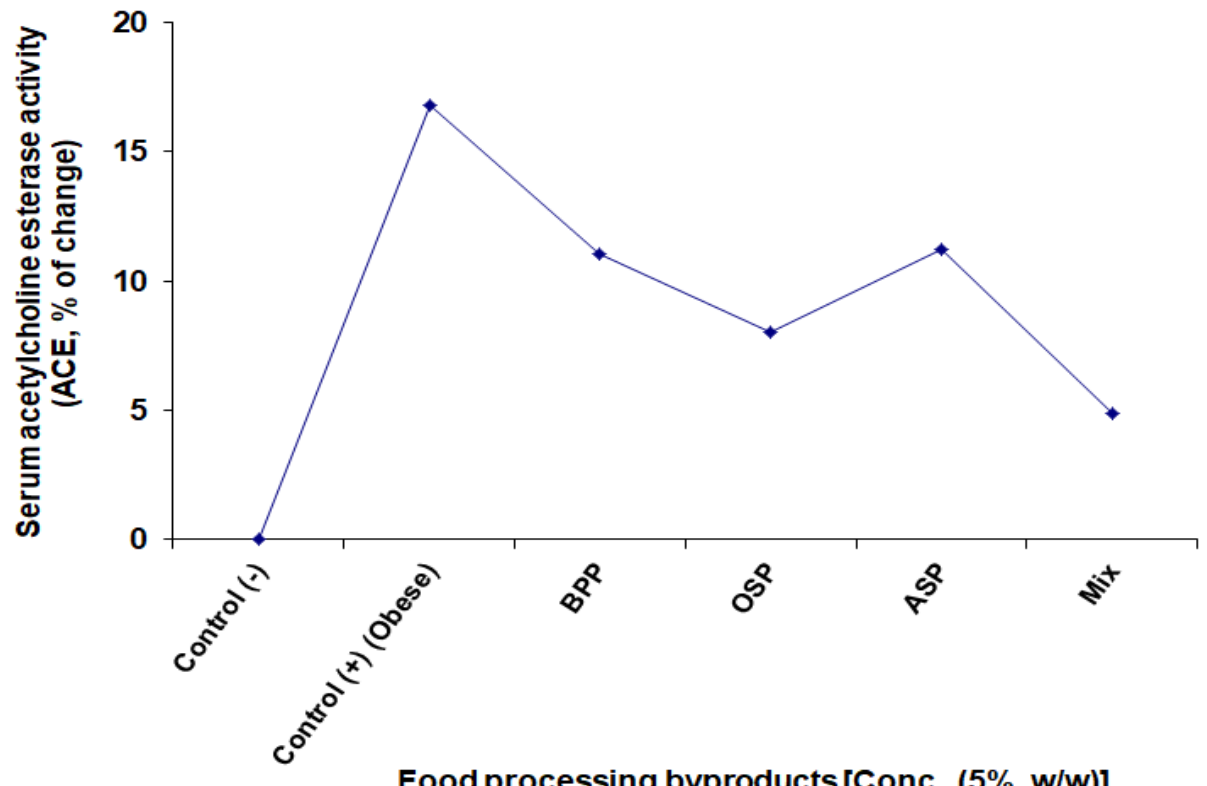

Fig. 3. The effect of selected food processing byproducts on serum acetylcholine esterase (as \% of change) of obese rats*

*BPP, banana peel powder; OSP, onion skin powder; ASP, apricot seeds powder and Mix, mixture of BPP, OSP and ASP by equal parts 
$\mathrm{AChE}$ represent an acetylcholine hydrolyzing enzyme that is accountable for the termination of cholinergic response. An increased AChE activity in brain excite memory deficits as well as oxidative stress (Melo et al., 2003). In present study, obesity induced increase in AChE activity. This observation is confirmed in several previous studies (Paes et al., 2006 and Zahra et al., 2017). They also found that long-term of pomegranate extracts feeding reduce the AChE activity. The increasing of AChE activity could be is attributed to $\mathrm{Ca}^{2+}$ influx-mediated oxidative stress caused by Amyloid beta peptides. Our data with the other explain the mechanism of anticholinesterase activity of food processing byproducts which may be due to antioxidant activities of their bioactive compounds such as phenolics, alkaloids and carotenoids. Such compounds protect of neural cell from OS insults by different mechanisms. One of these mechanisms is preventing the influx of $\mathrm{Ca} 2+$ despite high levels of ROS, increasing intracellular GSH and directly lowering levels of ROS (Ishige et al., 2001). These findings highlight the neuroprotective effects of food processing byproducts and one of mechanisms is the inhibition of AChE and the stimulation of antioxidant activities.

The effect of food processing byproducts on serum immunological parameters of obese rats

\section{a- Serum albumin content and protease activity}

The effect of selected food processing byproducts in immunological complications, serum albumin and protease activity, of obese rats were shown in Table (4) and Figure (4). Such data indicated that obesity induced a significant $(\mathrm{p} \leq 0.05)$ decreasing in albumin $-13.54 \%)$ and protease activity (-21.71\%) levels compared to the normal group. Alteration of BPP, OSP, ASP and their mixture exhibited significant $(\mathrm{p} \leq 0.05)$ increasing on serum dopamine and serotonin levels by the ratio of $10.34,-6.95,-7.96$ and $-8.80,-8.13,-10.56$ and $-4.24 \%$, and $-19.68,-16.52,-18.78$ and $-14.47 \%$, respectively. The highest improvement in immunological disorders induced by obesity in rats was recorded for the byproducts mixture treatment followed by OSP, ASP, and BPP, respectively.

In general, it is knowing that albumin is an important metal binding protein and sacrificial antioxidant that can bind metals (copper tightly and iron weakly) to its surface serving as a target for their related free radical reactions. Thus, albumin inhibits copper ion dependent lipid peroxidation (Gutteridge and Wilkins, 1983). It was reported that hypo-albuminaemia is most frequent in the presence of advanced chronic liver diseases. Hence decline in albumin can be deemed as a useful index of the severity of cellular dysfunction in chronic liver diseases. So, it is worthy to report that feeding with some food processing byproducts such BPP, OSP and ASP produced significant $(\mathrm{p} \leq 0.05)$ improvement in serum albumin compared to obese group. Such observations are in accordance with that reported by Sayed Ahmed, (2016) who found that pretreatment with plant parts such potato, onion and mango peels, and cauliflower leaves (contains almost the bioactive compounds found in the tested byproducts) the produced significant $(\mathrm{p} \leq 0.05)$ improvement in serum albumin compared to normal group. On the other side, several studies revealed that proteases enzymes could play an important role in immunological functions and humoral host defense (Troll and Kennedy, 1993; Elhassaneen, 1996 and Elmaadawy et al., 2016). Another studies highlighted the direct relationship between protease expression and protozoal virulence have implicated proteases as being involved in pathogenicity. In similar studies, protease activity was found decreased in obesity and its complications as found in the present study (Elmaadawy et al., 2016, Aly et al., 2017 and Elbasouny et al., 2019). Also, co-treatment of $\mathrm{CCl}_{4}$ and plant parts extracts exhibited therapeutic effects through increasing the immunotoxic effects i.e. albumin level and protease activity in liver cells

(Elhassaneen et al., 1997 and Elhassaneen and Tawfik, 2001). In the present study, the selected food processing byproducts i.e. ASP, ROSP, BPP and their mixture exhibited immune-modulatory potential. Immunomodulation is described as the ability of a nutrient, herb, or other substance to promote healthy immune function (Haider et al, 2019). Certain phytobioactive compounds (such as found in ASP, ROSP and BPP) have been shown in experimental studies to have immune-stimulating properties; that is, they appear to help stimulate viral defense mechanisms by activating immune cells such as macrophages, lymphocytes ( $\mathrm{T}$ and B-cell, and natural killer cell), and the cytokines (e.g., interleukin, interferon, and tumor necrosis factor) (Roesler, 1991 and Suresh and Vasudevan, 1994). That decreasing rate in immunotoxic effects was depending on the type of the food processing byproducts applied. With this manner, Singh et al., (2004) reported that the positive immune effects of five extracts/fractions of red onion peel which could attributed to their content of phenolics and flavonoids subsequently antioxidant and free radical scavenging activities. The present data with the others suggested that the highest therapeutic effect was recorded for the mixture of the selected food processing byproducts which could be attributed to the antagonism effects as the result of different phytobioactive compounds (Elmaadawy et al., 2016; Sayed Ahmed, 2016 and Aly et al., 2017) 
Table 4. The effect of selected food processing byproducts on immunological parameters of obese rats*

\begin{tabular}{|c|c|c|c|c|c|c|}
\hline \multirow[b]{2}{*}{ Value } & \multirow[b]{2}{*}{$\begin{array}{l}\text { Control } \\
(-) \\
\text { Std diet }\end{array}$} & \multirow[b]{2}{*}{$\begin{array}{c}\text { Control } \\
(+) \\
\text { Obese }\end{array}$} & \multicolumn{4}{|c|}{ Food processing byproducts $(5 \%, w / w)$} \\
\hline & & & $\begin{array}{c}\text { Banana peel } \\
\text { powder } \\
\text { (BPP) }\end{array}$ & $\begin{array}{c}\text { Onion skin } \\
\text { powder } \\
\text { (OSP) } \\
\end{array}$ & $\begin{array}{c}\text { Apricot seeds } \\
\text { powder } \\
\text { (ASP) }\end{array}$ & $\begin{array}{c}\text { Mixture } \\
\text { (BPP + OSP } \\
\text { + ASP }) \\
\end{array}$ \\
\hline \multicolumn{7}{|c|}{ Serum albumin level (Alb, g/L) } \\
\hline Mean & $51.42^{\mathrm{a}}$ & $44.46^{\mathrm{c}}$ & $46.89^{\mathrm{ab}}$ & $47.24^{\mathrm{ab}}$ & $45.99^{\mathrm{bc}}$ & $49.24^{\mathrm{a}}$ \\
\hline SD & 5.21 & 4.15 & 1.99 & 5.02 & 4.11 & 7.26 \\
\hline$\%$ of Change & 0.00 & -13.54 & -8.80 & -8.13 & -10.56 & -4.24 \\
\hline \multicolumn{7}{|c|}{ Serum protease activity (PA, U/L) } \\
\hline Mean & $3.57^{\mathrm{a}}$ & 2.79 & $2.87^{\mathrm{bc}}$ & $2.98^{\mathrm{bc}}$ & $2.90^{\mathrm{bc}}$ & $3.05^{\mathrm{b}}$ \\
\hline SD & 0.47 & 0.32 & 0.30 & 0.22 & 0.19 & 0.22 \\
\hline$\%$ of Change & 0.00 & -21.71 & -19.68 & -16.52 & -18.78 & -14.47 \\
\hline
\end{tabular}

* Means in the same row with different superscript letters are significantly different at $p \leq 0.05$.

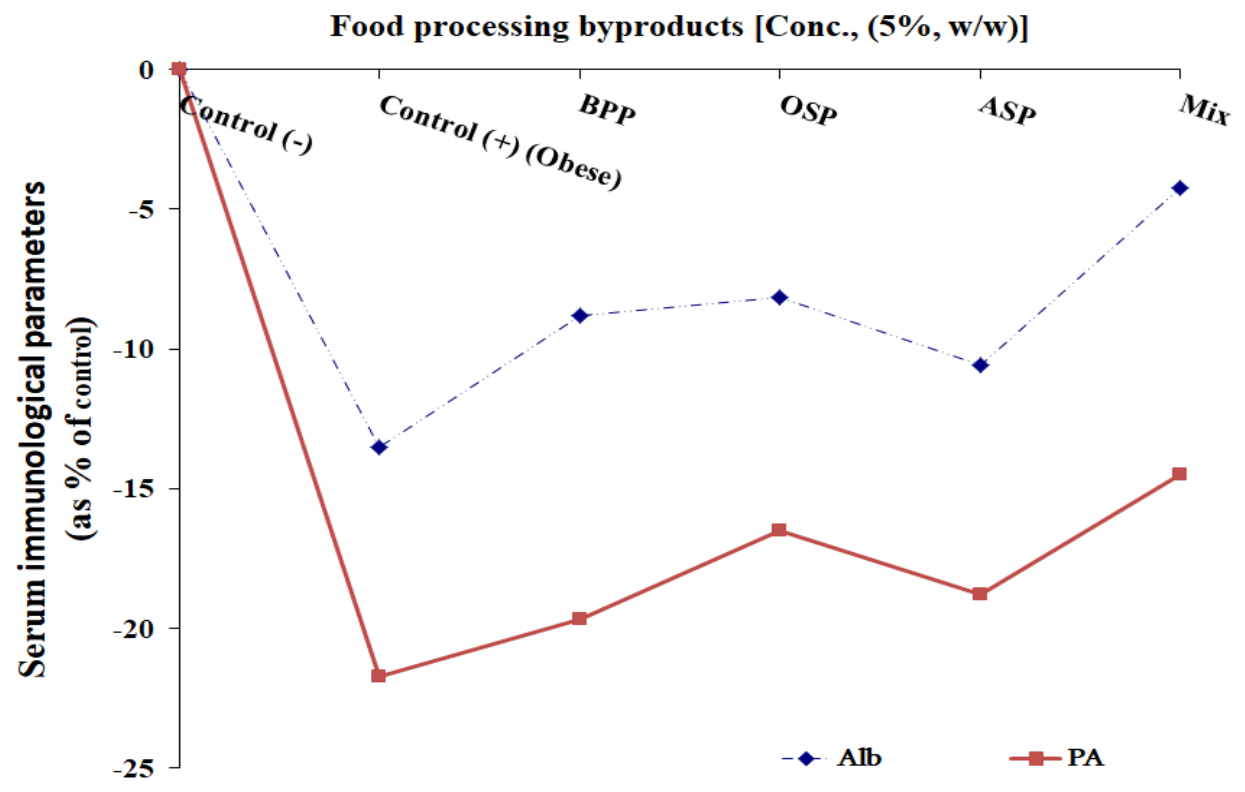

Fig. 4. The effect of selected food processing byproducts on immunological parameters concentration (as \% of control) of obese rats*

*BPP, banana peel powder; OSP, onion skin powder; ASP, apricot seeds powder and Mix, mixture of BPP, OSP and ASP by equal parts

\section{b-Tumor necrosis factor- $\alpha$ (TNF- $\alpha)$}

The effect of selected food processing byproducts in serum tumor necrosis factor- $\alpha$ (TNF- $\alpha$ ) obese rats was shown in Table (3) and Figure (3). Such data indicated that obesity induced a significant $(\mathrm{p} \leq 0.05)$ increasing in serum TNF- $\alpha(55.81 \%)$ level compared to the normal group. Alteration of BPP, OSP, ASP and their mixture exhibited significant $(\mathrm{p} \leq 0.05)$ decreasing on serum TNF- $\alpha$ level by the ratio of $25.58,17.83,22.48$ and $12.40 \%$, respectively. The highest improvement in serum TNF- $\alpha$ induced by obesity in rats was recorded for the byproducts mixture treatment followed by OSP, $\mathrm{BPP}$, and ASP, respectively. 
Table 5. The effect of selected food processing byproducts on serum TNF- $\alpha$ concentration (ng/L) of obese rats*

\begin{tabular}{|c|c|c|c|c|c|c|}
\hline \multirow[b]{2}{*}{ Value } & \multirow[b]{2}{*}{$\begin{array}{c}\text { Control } \\
(-) \\
\text { Std diet }\end{array}$} & \multirow[b]{2}{*}{$\begin{array}{c}\text { Control } \\
(+) \\
\text { Obese }\end{array}$} & \multicolumn{4}{|c|}{ Food processing byproducts $(5 \%, w / w)$} \\
\hline & & & $\begin{array}{c}\text { Banana peel } \\
\text { powder } \\
\text { (BPP) }\end{array}$ & $\begin{array}{c}\text { Onion skin } \\
\text { powder } \\
\text { (OSP) }\end{array}$ & $\begin{array}{l}\text { Apricot seeds } \\
\text { powder } \\
\text { (ASP) }\end{array}$ & $\begin{array}{c}\text { Mixture } \\
(\mathrm{BPP}+\text { OSP } \\
\text { + ASP })\end{array}$ \\
\hline Mean & $1.29^{\mathrm{c}}$ & $2.01^{\mathrm{a}}$ & $1.62^{\mathrm{ab}}$ & $1.52^{b}$ & $1.58^{b}$ & $1.45^{\mathrm{bc}}$ \\
\hline SD & 0.10 & 0.21 & 0.17 & 0.09 & 0.14 & 0.11 \\
\hline$\%$ of Change & 0.00 & 55.81 & 25.58 & 17.83 & 22.48 & 12.40 \\
\hline
\end{tabular}

$*$ Means in the same row with different superscript letters are significantly different at $\mathrm{p} \leq 0.05$.

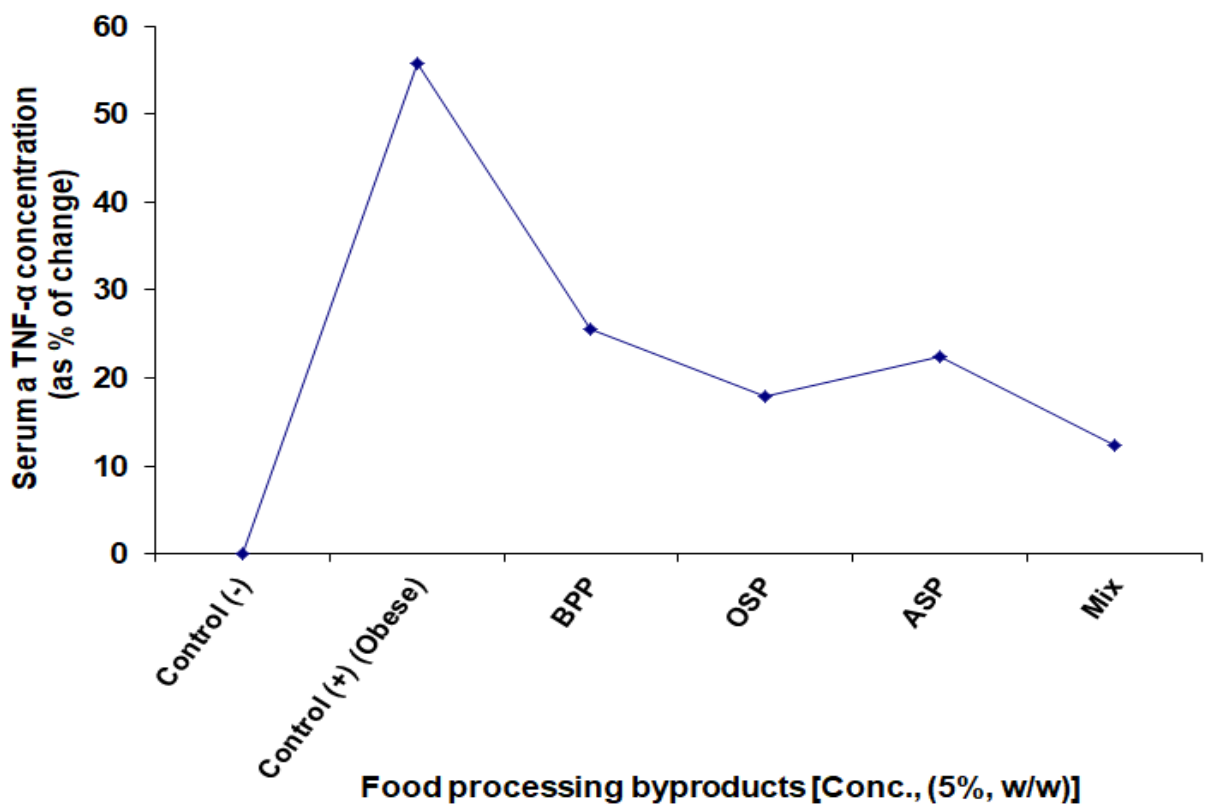

Fig. 5. The effect of selected food processing byproducts on serum TNF- $\alpha$ concentration (as \% of change) of obese rats*

*BPP, banana peel powder; OSP, onion skin powder; ASP, apricot seeds powder and Mix, mixture of BPP, OSP and ASP by equal parts

In general, TNF- $\alpha$ is a pro-inflammatory cytokine, and plays an important role in initiating the tissue inflammatory reaction (Kim et al., 2003). TNF- $\alpha$ functions including increases vascular permeability, promotes leukocyte adhesion of vascular endothelial cells, stimulates IL-1 production by vascular endothelial cells endothelin, and other inflammatory mediators, leading to tissue inflammation and damages endothelial cells. On the other side, TNF- $\alpha$ stimulates neutrophil degranulation "outbursts," which produces reactive oxygen species (ROS), proteases and lipids, leading to tissue damage (Gao, 1999 and Elhassaneen et al., 2016e). Additionally, in inflammatory reactions, TNF- $\alpha$ is synthesized and secreted by mononuclear macrophages, by autocrine and paracrine mechanisms, releasing IL-1, IL-6, and IL-8, causing a "cascade effect" and aggravating tissue damage (Bentrem and Joehl, 2003). Data of the present study indicated that serum TNF- $\alpha$ levels in food processing byproducts treated groups are significantly lower than in obese group. $(P \leq 0.05)$. This data with others suggests that food processing byproducts may prevent development of obesity complications related to immunity probably by reducing vascular permeability and the release of inflammatory cells, inflammatory mediators and inflammatory cell infiltration relieving edema, and inhibiting generation of IL-1, IL-6, and IL-8 (Elhassaneen et al., 2016-e). This observation was confirmed by Junzhang et al., (2014) who reported that brown algae bioactive compounds (such found in BPP, OSP and ASP) may prevent the development of radiation esophagitis, perhaps by inhibiting the generation and release of the inflammatory response factors including TNF- $\alpha$.

In conclusion, the present study has demonstrated that the potency of the selected food processing byproducts including BPP, OSP and ASP to ameliorate 
the neurological and immunological complications /disorders in obese rats. Improving the neurological complications includes increasing the serum neurotransmitters (dopamine and serotonin) level and decreasing the acetylcholine activity. While, improving the immunological complications includes increasing the albumin level and protease activity in serum. These findings provide a basis for the use of the selected food processing byproducts in the prevention and early treatment of obesity. Also, the data support the benefits of dietary modification, including bioactive compounds in food processing byproducts supplementation, in alleviating the conventional neurological and immunological disorders associated obesity. Finally, more research must be done on the future to elucidate the realized benefits from dietary plant parts intake, such food processing by products, on obesity disease and its complications.

\section{REFERENCES}

AIN, American Institute of Nutrition. 1993. Purified diet for laboratory Rodent, Final report. J. Nutrition. 123:19391951.

Akitane, M., L. Jiankang and K. Motoko. 1994. Free radical scavenging by brain homogenate: Implication to free radical damage and antioxidant defense in brain. Neurochemistry International. 24(3): 201-207.

Albert, M.S., S.T.DeKosky, D.Dickson, B.Dubois, H.H. Feldman and N.C. Fox. 2011. The diagnosis of mild cognitive impairment due to Alzheimer's disease: recommendations from the National Institute on AgingAlzheimer's association workgroups on diagnostic guidelines for Alzheimer's disease. Alzheimers Dement.7(3):270-279.

Aly, A., G.Elbassyouny and Y.Elhassaneen. 2017. Studies on the antioxidant properties of vegetables processing byproducts extract and their roles in the alleviation of health complications caused by diabetes in rats. Proceeding of the $1^{\text {st }}$ International Conference of the Faculty of Specific Education, Kafrelsheikh University, "Specific Sci., their Developmental Role and Challenges of Labor Market" 124,24-27. October, Sharm ElSheikh, Egypt.

Alzahrani, B., T. J. Iseli and L. W. Hebbard. 2014. Non-viral causes of liver cancer: does obesity led inflammation play a role? Cancer Lett. 345:223-229.

Beattic, J., A. Crozier and G. Duthie. 2005. Potential Health Benefits of berries. Current Nutrition and Food Sci. 1: 71 86.

Bedawy, O.E. 2008. Relationship between phyto-sulphur compounds and lipid of blood in experimental animals M.Sc. Thesis, Faculty of Home Economics, Minoufiya University, Shebin El-Kom, Egypt.

Bentrem, D.J. and R.J. Joehl. 2003. Pancreas: healing response in critical illness. Crit Care Med. 31(8): 582-589.
Bonet, M., A.Jose, R.Joan and P. Andreu. 2015. Carotenoids and their conversion products in the control of adipocyte function, adiposity and obesity. Archives of Biochemistry and Biophysics. 572: 112-125.

Bray, G.A. 2004. "Medical consequences of obesity". J. Clin. Endocrinol. Metab. 89 (6): 2583-9.

Campbell, J. A. 1963. Methodology of Protein Evaluation. RAG Nutr., Document R.10, Led. 37. June Meeting, New York, NY.

Constance, F., A.John, D.Brian, M.Theodore and J. Timothy. 2003. Meal Pattern Analysis of Diet-Induced Obesity in Susceptible and Resistant Rats. Obesity Research. 11(7): 845-851.

Coulibaly, S., G. J. Nemlin and A. Kamenan. 2007. Chemical composition, nutritive and energetic value of plantain (Musa SSp.) hybrids CRBP 14, CRBP.39, FHIA. 17, FIJT. 21 and orishele variety., Tropiculture 25 (1): $2-6$.

Drury, R.A. and E.A. Wallington. 1980. Carleton's Histological Technique. 5th Edition, Oxford University Press, New York.

Elbasouny, G., N. Shehata, and Y.Elhassaneen. 2019. Feeding of some selected food industries by-products induced changes in oxidants/antioxidant status, lipids profile, glucose and immunological parameters of blood obese rats. The 6th Scientific and 4th International Conference "The Future of Specific Education and people with Special Needs in Light of the Concept of Quality", 24-26 February 2019, Faculty of Specific Education, Ain Sokhna University, El-Ain El-Soghna, Egypt.

Elhassaneen, Y. 1996. Chemical and technological studies on the pollution of environment with pesticides and polycyclic aromatic hydrocarbons. Ph. D. Thesis, Faculty of Agriculture, Mansoura University, Mansoura, Egypt.

Elhassaneen, Y. A., N. F. Safaa El-Waseef and S.A. Sarah. 2016-c. Bioactive Compounds and Antioxidant Potential of Food Industry By-products in Egypt. American J. of Food and Nutrition. 4 (1): 1-7.

Elhassaneen, Y. A. R., Sherif and B. Reham. 2016-b. Antioxidant activity of methanol extracts from various plant parts and their potential roles in protecting the liver disorders induced by benzo $(a)$ pyrene. Public Health International. 2 (1): 38-50.

Elhassaneen, Y. A., G.Samia, S.Ryeaan and Y. Mayada. 2016-d. Onion, orange and prickly pear peel extracts mixed with beef meatballs ameliorate the effect of alloxan induced diabetic rats. American J. of Pharmacology and Phytotherapy. 1 (1): 15-24.

Elhassaneen, Y. A., O.M.Khater, L.M. Tawfeek and M. Sanad. 1997. In vitro biochemical studies on pollution of fish with paper industry effluents. J. of Home Economics. 7 (2-3): 183-196.

Elhassaneen, Y. and L.Tawfik. 2001. Cooking oil fumes used in some Egyptian food preparation as sources of toxic and carcinogenic substances. Fayoum J. Agricultural Research and Development. 15 (2): 66-79. 
Elhassaneen, y., S.El-Waseef, N. Fathy and A. S. Sayed. 2016-a. Bioactive compounds and antioxidant potential of food industry by-products in Egypt. American J. of Food and Nutrition. 4 (1): 1-7.

Elhassaneen, Y., S.Sherif and S.Mona. 2016-e. The Potential Effects of Reishi Mushroom (Ganoderma lucidum) Consumption on Bone Health Indices and Serum Minerals Profile Disorders Induced by $\mathrm{CCl} 4$ on Rats. Pyrex J. of Medicinal Plant Research. 2 (1): 1-7.

Elhassaneen, Y.A. and M.I.Sanad. 2009. Phenolics, Selenium, Vitamin C, Amino Acids and Pungency Levels and Antioxidant Activities of Two Egyptian Onion Varieties. American J. of Food Technology. 4(6): 241-254".

Elmaadawy, A., M. A.Rasha and Y.A. Elhassaneen. 2016. Oxidative Stress and antioxidant defense systems status in obese rats feeding some selected food processing byproducts applied in bread. J. of Home Economics.26 (1): 55-91.

El-Safty, A. E. 2012. Production of some important nutritional and functional compounds from the by-products of food processing companies " Ph.D. Thesis in Nutrition and Food Sci., Faculty of Home Economics,

Erdogan-orhan, I. and M.Kartal. 2010. Food Researsh International. 432 (7015):281-282.

Gao, B.H. 1999. The effects of TNF on inflammation. Yi Shi Jin Xiu Za Zhi. 22(11): 55-56.

Gowenlock, A. H. 1988. Varley's practical clinical biochemistry. $6^{\text {th }}$ ed., Heinemann Medical Books, London, UK.

Gukovsky, I., N.Li, J.Todoric, A. Gukovskaya and M.Karin. 2013. Inflammation, autophagy, and obesity: common features in the pathogenesis of pancreatitis and pancreatic cancer. Gastroenterology. 144:1199-1209 .

Haider, I., G.Sarmad and N. Hassan. 2019. The Effect of Nutrition on Immune System Review Paper. Food Sci. and Quality Management. 90: 31-35.

Hassan, H. H. 2015. The effect of some food products mixed with plant parts on blood sugar levels of rats" Ph.D. Thesis in Nutrition and Food Science, Faculty of Home Economics, Minoufiya University, Shebin El-Kom, Egypt.

Hassan, A. 2011. "The effect of phytochemicals on prevention and/or treatment of liver cancer induced by some food pollutants" Ph.D. Thesis in Nutrition and Food Sci., Faculty of Home Economics, Minoufiya University, Egypt.

Hegested, D.M., R.C.Mills, C.A. Elvehjen and E.B. Hart. 1941. Salt mixture. J. Biol. Chem. 138:459.

Hertog, M., P.Hollman, M.Katan and D.Kromhout. 1993. Estimation of daily intake of potentially anticarcinogenic flavonoids and their determinants in adults in The Netherlands . Nutr. Cancer. 20:21-29.

Hugo J. O., C.David, H.Ernestina and B.Gerardo. 2016.The Role of Dopamine and Its Dysfunction as a Consequence of Oxidative Stress. Oxidative Medicine and Cellular Longevity, Article ID. 9730467: 1-13.
Ishige K, D.Schubert and Y.Sagara. 2001. Flavonoids protect neuronal cells from oxidative stress by three distinct mechanisms. Free Radic Biol Med. 30(4):433-46.

Kim, G.Y., S.I. Roh. and S.K. Park. 2003. Alleviation of experimental septic shock in mice by acidic polysaccharide isolated from the medicinal mushroom Phellinus linteus. Biol. Pharm. Bull. 26(10): 1418-1423.

Kumar, S. P. S., D.Bhowmik, S.Duraivel and M.Umadevi. 2012. Traditional and medicinal uses of banana., J. of pharmacognosy and phytochemistry. 1 (3): $51-63$.

L'opez-P'erez, S., A. Morales-Villagran and L. Medina-Ceja. 2015. Effect of perinatal asphyxia and carbamazepine treatment on cortical dopamine and DOPAC levels, J. of Biomedical Sci. 22, article 1.

Lam, D. D., A. S.Garfield, O. J.Marston, J. Shaw and L. K.Heisler. 2010. Brain serotonin system in the coordination of food intake and body weight. Pharmacol Biochem Behav. 97: 84-91.

Loef, M. and H. Walach. 2013. Midlife obesity and dementia: meta-analysis and adjusted forecast of dementia prevalence in the united states and china. Obesity. 21(1):E51-55.

Mahran, M, Z., M. E.Ghada and Y.A. Elhassaneen. 2018-a. Preventive effects of onion skin powder against hepatotoxicity in rats treated with $\operatorname{benzo}(a)$ pyrene. Proceeding of the Annual Conference (13 ${ }^{\text {th }}$ Arab; $10^{\text {th }}$ International), 11-12 April, Faculty of Specific Education, Mansoura University, " Higher Education in Egypt and the Arab World in the Light of Sustainable Development Strategies", Mansoura, Egypt.

Mahran, M. Z., R. G.Abd Elsabor and Y. A.Elhassaneen. 2018-b. Effect of feeding some selected food processing by-products on blood oxidant and antioxidant status of obese rats. Proceeding of the $1^{\text {st }}$ Scientific International Conference of the Faculty of Specific Education, Minia University, "Specific Education, innovation and labor market" 16-17. Minia, Egypt.

Melo, J.B., P.Agostinho and C.R.Oliveira. 2003. Involvement of oxidative stress in the enhancement of acetylcholinesterase activity induced by amyloid betapeptide. Neurosci Res.45(1):117-27.

Mokdad, A. H. 2003. Prevalence of obesity, diabetes, and obesity-related health risk factors, 2001. JAMA. 289: 7679.

Morton, G. J., Meek, T. H. and Schwartz, M. W. (2014). Neurobiology of food intake in health and disease. Nat Rev Neurosci 15, 367-378.

Mousseau, D. and G.p. Baker. 2012. Recent developments in the regulation of monoamine oxidase form and function: is the current model restricting our understanding of the breadth of contribution of monoamine oxidase to brain dysfunction? Current Topics inMedicinal Chemistry. 12(20): 2163-2176.

Nam, S., K.Keunyoung, S.Bum, Kim, I.Hyung-Jun, H. L.Seung, K.Seong-Jang, K. In Joo and P.Kyoungjune. 2018. The Effect of Obesity on the Availabilities of Dopamine and Serotonin Transporters. SCIeNTIFIC RePorts. 8:1-6. 
Ngwang, N. R. 2015.The usage of banana (Musa Acuminata) for Novel beverage production., International J. of bioscience, bioinformatics. 5 (1): $62-65$.

NRC, National Research Council. 1996. Guide for the Care and Use of Laboratory Animals Washington: National Academy Press. Obtained from hypertensive-diabetes rats. Fundam Clin Pharmacol. 10:329-336.

OECD, Organisation for Economic Co-operation and Development member countries. 2017. Obesity Update. www.oecd.org/health/obesity-update.htm.

Onyeneho, S. N. and N. S.Hettiarachchy. 1993. Antioxidant activity, fatty acids and phenolic acids composition of potato peels. J. of the Sci. of Food and Agriculture. 62:345-350.

Paes, A.M., S.R.Carniatto, F.A.Francisco, N.A. Brito and P.C.Mathias. 2006. Acetylcholinesterase activity changes on visceral organs of VMH lesion-induced obese rats. The International J. of neuroscience. 116(11):1295-302.

Pannacciulli, N., A. Del Parigi, K. Chen, D.S.N. Le, E.M. Reiman and P.A. Tataranni. 2006. Brain abnormalities in human obesity: a voxel-based morphometric study NeuroImage. 31(4):1419-25.

Pistell, P.J., C.D.Morrison, S.Gupta, A.G.Knight, J.N. Keller and D.K. Ingram. 2010. Cognitive impairment following high fat diet consumption is associated with brain inflammation. J. Neuroimmunol. 219 (1-2):25-32.

Ragab, M., M. F. Osman and M. S. Gouda. 2016. Banana (musa Sp.) peel as source of pectin and some food nutrients., J. Agric. Res. Kafr El-Sheikh univ. 42 (4): 88 102.

Rinderrnecitt, H., M.C.Geokas, P.Silverman and B.J. Haverback.1968. A new ultrasensitive method for the determination of proteolytic activity. Clin. Chim. Acta.21: 197-203.

Rodriguez, D. S., M.Hadley and E. T. Holm. 1994. Potato peel waste: Stability and antioxidant activity of a freeze-dried extract. J. of Food Sci. 59(5): 1031-1033.

Roesler, J. 1991. Application of purified polysaccharides from cell cultures of the plant Echinacea purpurea to test subjects mediates activation of the phagocyte system. Int J. Immunopharmacol. 13:931-41.

Saad, A. S. H., A. H.Shahinaz, Y.A. Elhassaneen and S.Mohamed. 2018. Utilization of mango, onion and potato peels as sources of bioactive compounds in biscuits processing. bioscience research. 15(4): 3647-3657.

Sayed Ahmed, S. 2016. Nutritional and technological studies on the effect of phytochemicals on obesity injuries and their related diseases by using experimental animals. Ph.D. Thesis in Home Economics (Nutrition and Food Sci.), Faculty of Specific Education, Port Said University. Egypt.

Schieber, A., F. C. Stintzing and R. Carle. 2001. By-products of plant food processing as a source of functional compounds-recent developments. Trends in Food Sci. and Technology. 12(11):401-413.

Suresh, K. and D. M. Vasudevan. 1994. Augmentation of murine natural killer cell and antibody dependent cellular cytotoxicity activities by Phyllanthus emblica, a new immunomoldulator. J. Ethnopharmacol. 44:55-60.

Tahoon, S. R. 2019. Hepatoprotective effect of Apricot and Plum kernel on carbon tetrachloride induced hepatic rats ". M.SC. Thesis in Nutrition and Food Science, Faculty of Home Economics, Minoufiya University, Egypt.

Thomsen, G. 2013. No correlation between body mass index and striatal dopamine transporter availability in healthy volunteers using SPECT and [123I]PE2I. Obesity (Silver Spring). 21: 1803-1806.

Troll, W. and A.R.Kennedy. 1993. Protease inhibitors as cancer chemopreventive agents. Plenum Press, New York.

Velioglu, Y.S., G.Mazza, L. Gao and B.D. Oomah. 1998. Antioxidant activity and total phenolics in selected fruits, vegetables and grain products. J. Agric. Food Chem. 46 (10): 4113- 4117.

Waldron, K.W. 2001. Useful ingredients from onion waste. J. Food Sci. Technol. 15(2):38-41.

WHO. 2006. Report. Puska, P. Nishida, C. Porter, D. Obesity and overweight. Rome, Italy.

WHO. and L.Dini. 2006. Strategic directions for improving nutritional status of populations using the lifecycle approach. Assignment Report. SEA-NUT-167.

Zahra, A., G. Asma, T.Mouna, M.Férièle, A.Fatma, E.Abdelfateh and H.Mohamed. 2017. Effect of pomegranate extracts on brain antioxidant markers and cholinesterase activity in high fat-high fructose diet induced obesity in rat model. BMC Complementary and Alternative Medicine. 17: 1-9. 


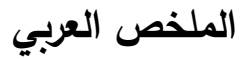

الآثار المحتملة للنواتج الثانوية لمصانع الأغذية على الاضطرابات العصبية والمناعية للفئران المصابة

\section{بالسمنة}

ايمان بدوى محرم ، ألاء أسامة عبد السلام حسن أبو رية ، يوسف عبد العزيز الحسانين

تليها، BSP ، OSP ، ASP على الترتيب. على الجانب

الآخر، أظهرت النتائج فاعلية النواتج الثانوية المختارة

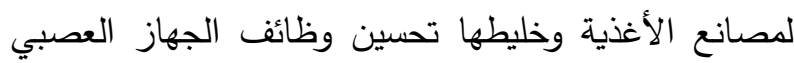
(محتوى الدوبامين والسيروتونين ونشاط انزيم أسيتيل كولين استريز) والمناعة (محتوى الألبومين وعامل نخر الورم- ألفا ولنافين

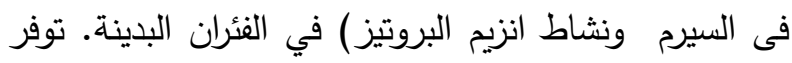
هذه النتائج أساسًا لاستخدام المنتجات الثانوية للصصانع الأغذية للوقاية والعلاج المبكر من السمنة. كما تدعم تلك الكاتف

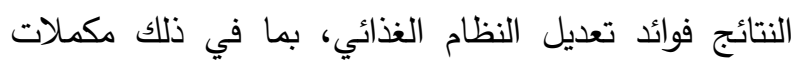

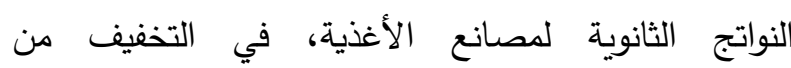
الاضطرابات العصبية والمناعية المرتبطة بالسمنة. الكلمات المفتاحية: وزن الجسم، قشر الموز، قشر البصل، بذور المشم، انزيم الأستيل كولين استريز، التهن، الدوبامين، السيروتونين، الألبومين، نثاط النزيم البين كولين البروتيز

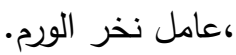

أجريت الدراسة الحالية بهدف استكثاف تأثير ثلاثة من

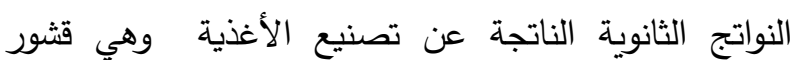
البصل والموز وكذلك بذور المشمش على الاضطرابات العصبية والمناعية للفئران المصابة بالسمنة. أوضحت النئي النتائج أن تغذية الفئران المصابة بالسمنة التي يسبها النظام الغذائي المحث للسمنة (DIO) إلى زيادة وزن الجسم مقارنة بالمجموعة الضابطة السالبة. وفي نهاية التجربة (1 أسابيع) سجلت الفئران من المجموعة الضابطة السالية زيادة مقدارها

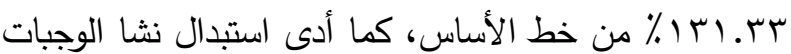
بمسحوق قشر الموز (BPP) ، ومسحوق قشر البصل (OSP) ، ومسحوق بذور المشمش, (ASP) ومخلوطهم ( ASP + OSP ) +بأجزاء متساوية) إلى انخفاض كبير في وزن الجسم (APP

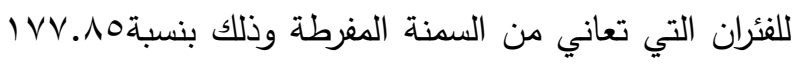

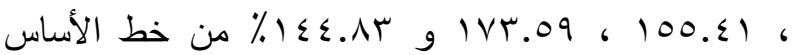
على التوالي. كما تم تسجيل التأثير الأعلى على انخفاض الوزن للمجموعة التى تغذت على المخلوط من أجزاء النبات 